\title{
Increase in neutrophil count after repeated exposure of Plasmodium berghei-infected mice to artemisinin
}

\author{
Lilik Maslachah* and Rahmi Sugihartuti*
}

\begin{abstract}
\section{BACKGROUND}

Leukocytes play an important role in the elimination of malaria infection. The leukocyte profile upon elimination of the malaria parasites that have been exposed to antimalarials and are subsequently capable of faster growth has not been researched. The aim of this research was to evaluate the role of mouse leukocytes in the elimination of parasites as shown by the leukocyte profile.
\end{abstract}

\section{METHODS}

An experimental research with post test only control group design was conducted involving 24 male mice of the Swiss Albino strain weighing $20 \mathrm{~g}-30 \mathrm{~g}$, and 2.5 months old. They were randomized into four groups: two control groups (K1, KP) and two treatment groups (P1, P4). Artemisinin at a dose of $0.04 \mathrm{mg} / \mathrm{g}$ body weight was given to the mice for 3 days, starting 2 days after infection. The leukocyte profile was observed on the $2^{\text {nd }}, 5^{\text {th }}, 8^{\text {th }}$, and $10^{\text {th }}$ day after infection. The results were analyzed by two-way Anova.

\section{RESULTS}

As shown in treatment control group KP and treatment group $\mathrm{P} 4, P$. berghei that had been passaged in the mice and were still viable after repeated exposure to artemisinin, may cause changes in leukocyte profile. On the $10^{\text {th }}$ day of infection, the neutrophil percentage in group P1 showed a significantly different decrease when compared with the other groups $(\mathrm{K} 1, \mathrm{KP}$ and $\mathrm{P} 4)(\mathrm{p}<0.05)$.

\section{CONCLUSION}

Repeated exposure to artemisinin of mice infected with $P$. berghei can cause changes in neutrophil profile in mice.

Keywords: Artemisinin, leukocytes, repeated passage, P. berghei
*Veterinary Pharmacy Laboratory, Department of Basic Veterinary Medicine,

Faculty of Veterinary Medicine, Airlanggga University

\section{Correspondence:}

Dr. Lilik Maslachah, drh., M.Kes. Department of Basic Veterinary Medicine,

Faculty of Veterinary Medicine, Airlanggga University C Campus Mulyorejo Surabaya 60115 Phone: +6231-5992785

Fax : +6231-5993015

Email: lilik.maslachah@yahoo.com

Univ Med 2017;36:49-58

DOI: $10.18051 /$ UnivMed.2017.v36.49-58 pISSN: 1907-3062 / eISSN: 2407-2230

Received October 17, 2016

Accepted for publication April 20, 2017

This open access article is distributed under a Creative Commons Attribution-Non Commercial-Share Alike 4.0 International License 


\section{INTRODUCTION}

Malaria is still a public health problem in more than 95 countries around the world including Indonesia. In 2015 there were approximately 214 million cases of malaria with 438.000 deaths, mostly occurring in African children under 5 years of age. ${ }^{(1)}$

The increased incidence of morbidity and mortality of malaria is rapid and widespread due to increased parasite resistance to antimalarial medications. The new drugs for malaria treatment which are used to date are artemisinin and its derivatives. The effect of these drugs is faster than that of other anti-malarial drugs because they have more complex mechanisms of action. However, there have been indications that the Plasmodium parasite has become resistant to these drugs. ${ }^{(2)}$ This was shown clinically in two patients in Cambodia who were infected with $P$. falciparum, in whom the parasites had become resistant to artesunate. ${ }^{(3)}$ The research results showed that there has been decreasing efficacy of the combination of artesunate-mefloquine in falciparum malaria in Cambodia. ${ }^{(4)}$ Currently, the resistance of $P$. falciparum to artemisinin has been detected to have occurred in five countries including Cambodia, Lao People's Democratic Republic, Myanmar, Thailand and Vietnam. ${ }^{(1)}$

The results of an in vitro study of $P$. falciparum that were repeatedly exposed to artemisinin showed increased inhibitory concentration $50 \%\left(\mathrm{IC}_{50}\right)$, dormant phenotypic changes, and faster growth of viable Plasmodium evolving from dormant forms. Moreover, artemisinin exposure also can cause mutations in the pfatpase 6 gene. ${ }^{(5)}$ It is believed that the artemisinin resistance occurs because of mutations in pfcrt, pfmdrl, pfatpase 6 and pfk 13. ${ }^{(6,7)}$

The presence of parasite pressure on the use of medicines at subcurative doses will lead to the development of new parasite strains that can survive the medicine. The results of this research are to be viewed as indicating an emergency, because there will be a risk of the development of in vivo resistance in humans, which will be one of the health problems in the world. Moreover, there is no substitute for artemisinin. Malaria treatment failure with artemisinin and its derivatives will open an era of untreatable malaria.

Experimental in vivo studies using rodent malaria are used to support the translation of laboratory studies into clinical studies. Since the pathologic mechanism for the spectrum of malaria in humans is not known clearly, these experimental studies can be used to explain the mechanism of artemisinin resistance in vivo by using mice that are infected with $P$. berghei. Because of the resilience and virulence of the malaria parasites in antimalarial resistance, there is a need to do research to develop effective strategies for malaria control. However, it is really difficult to do research in endemic areas because there are many confounding factors, such as the cloning of multiple infections from infective mosquito bites, which is impossible to do in humans because of ethical factors. So that this research is using rodent malaria as an in vivo drug resistance model of human malaria by exposing $P$. berghei to artemisinin. The effective dose of artemisinin that is used is $99 \%\left(\mathrm{ED}_{99}\right.$ : $200 \mathrm{mg} / \mathrm{kg}$ body weight of the mice), and is given repeatedly to the mice upon parasite passage.

$P$. berghei is one of the species of Plasmodium that infect rodents. Many studies of malaria use P. berghei with mice as hosts, because $P$. berghei has the same life cycle and morphology as the Plasmodium parasites that infect humans. Molecular analysis show that there are similarities between rodent malaria and P. falciparum malaria. In order to support in vivo studies on $P$. falciparum drug resistance, $P$. berghei can be used as a model. ${ }^{(8)}$

Results of research by Darlina et al. ${ }^{(9,10)}$ showed that leukocytes play a role in the protective mechanism during malaria infection, as is indicated by the increasing numbers of leukocytes, lymphocytes, and monocytes and decreasing rates of parasitemia in mice that have been infected with irradiated $P$. berghei. 
One study showed that artemether, artesunate and artemisinin markedly decreased the leukocyte count after $24 \mathrm{~h}$ of treatment. Artemether and artesunate showed the highest efficacy in rescuing mice with late-stage cerebral malaria and rapidly decreased leukocyte accumulation in the brain. ${ }^{(11)}$ The results of the present study can give an idea of the leukocyte profile in hosts infected with plasmodium that have been repeatedly exposed to artemisinin. This is not possible in humans because of ethical considerations, therefore the results of the animal studies can be used for improvements in the treatment of malaria infection.

Leukocytes are part of the blood that are vital to the body defenses against infection. The objective of the present study was to evaluate the effect of artemisinin on leukocyte profile in mice infected with $P$. berghei, so that this research was conducted to determine the changes in leukocyte profile during the development of artemisinin resistance in mice infected with $P$. berghei upon passage of $P$. berghei that had been exposed repeatedly to antimalarial drugs,

\section{METHODS}

\section{Research design}

This research was an experimental research with post test only control group design. The parasite that was used to infect the mice was $P$. berghei ANKA strain. The experimental animals were 2.5 months old male Swiss albino mice weighing $20 \mathrm{~g}-30 \mathrm{~g}$. The artemisinin was of analytical grade from Sigma Chemical Co. Leukocyte examinations were conducted at the Faculty of Veterinary Medicine, Airlangga University, from June to October 2015.

\section{Research sample}

This research used twenty four male mice of the Swiss Albino strain, weighing $20 \mathrm{~g}-30 \mathrm{~g}$, and 2.5 months old. Each group consisted of 6 treated mice, with one mouse as the donor. The sample size was determined by Federer's formula. The animals were obtained from the animal facility at the Veterinary and Pharmaceutical Center (Pusat Veteriner dan Farmasi, Pusvetma), Surabaya.

\section{Research procedure}

Mice were intraperitoneally infected with mouse red blood cells (RBC) containing $1 \times 10^{5}$ P.berghei per $0.2 \mathrm{ml}$. The infection was detected by daily microscopic examination of the erythrocytes in thin blood smears taken from the tail vein of the mice and stained with $20 \%$ Giemsa. The mice were randomized into four groups, consisting of two control groups (K1, $\mathrm{KP})$ and two treatment groups (P1, P4).

In the treatment group $\mathrm{P} 1$, the mice were infected with $P$. berghei and 48 hours later treated with a single administration of artemisinin. Subsequently the parasites in the blood of P1 animals were passaged into another group of animals (P2), who were then given 2 artemisinin treatments. The procedure was repeated for groups $\mathrm{P} 3$ and $\mathrm{P} 4$, which were infected with blood from $\mathrm{P} 2$ and $\mathrm{P} 3$ donors, respectively, and received 3 and 4 artemisinin treatments, respectively. The control group $\mathrm{K} 1$ consisted of mice who were infected with P.berghei and were untreated (did not receive artemisinin), while treatment control group KP consisted of untreated mice who were infected with P.berghei that had previously been treated four times with artemisinin.

Details of the treatment are as follows: Treatment group P1 comprised six mice that had been inoculated with RBC containing $1 \times 10^{5} P$. berghei in $0.2 \mathrm{ml}\left(\mathrm{D}_{0}\right)$ and were then treated with the artemisinin "4-day test" (4-DT) at the $\mathrm{ED}_{99}$ dose of $200 \mathrm{mg} / \mathrm{kgBW}$ for 3 days, starting 48 hours after infection $\left(D_{2}\right)$. After that, the parasitemia rate was monitored and calculated at 120 hours after infection. After the parasitemia rate was higher than $2 \%$ of $\mathrm{RBC}$, one mouse was used as donor of parasites to be passaged to 5 new mice. Then, 48 hours post infection, the 5 new mice were treated artemisinin at the same $\mathrm{ED}_{99}$ dose for 3 days and so on up to 4 passages (P2, P3, P4). The control group K1 contained 
five mice inoculated with $0.2 \mathrm{ml} \mathrm{RBC}$ containing $1 \times 10^{5} P$. berghei that had never been treated with artemisinin $\left(D_{0}\right)$ and were left untreated. Treatment control group (KP) contained six mice inoculated with $0.2 \mathrm{ml} \mathrm{RBC}$ containing $1 \times 10^{5} P$. berghei that had previously been treated 4 times with artemisinin $\left(\mathrm{D}_{0}\right)$ and were left untreated. Parasite development was followed in all treatment groups until 10 days after infection. ${ }^{(12,13)}$

\section{Leukocyte differential count}

The leukocyte differential count was done to represent one of the immune system parameters that plays an important role in malaria infection. The leukocyte differential count was done at 48 hours, and on the $5^{\text {th }}, 8^{\text {th }}$ and $10^{\text {th }}$ day post-infection, by making thin blood smears taken from the mouse tail vein, fixed with methanol for 5 minutes, put in a Giemsa staining solution for 20 minutes, washed with running water with the slide in a tilted position, and dried in the air. The leukocyte differential count was determined under the light microscope at 1000x magnification. Every 100 leukocytes that were found were counted and grouped into neutrophils, eosinophils, basophils, lymphocytes, and monocytes. The leukocytes were counted in a number of visual fields throughout the smear, the examination starting from the center of the smear, proceeding parallel to the edge of the smear, then moving back and forth until a total leukocyte count of 100 was reached. The proportions of the types of leukocytes was expressed in percentages. ${ }^{(10)}$

\section{Data analysis}

The data on the leukocyte profile was processed with ANOVA. If there were any significant differences, the multiple comparisons test was done using SPSS 17.0, with the level of significance set at $5 \%$ to determine differences in treatment.

\section{Ethical clearance}

This research has been approved by the ethics committee of the Faculty of Veterinary
Medicine, Airlangga University, on June $3^{\text {rd }} 2015$ with certificate number No. $464 \mathrm{KE}$.

\section{RESULTS}

Table 1 and Fig. 1A show the resulting neutrophil percentage in $\mathrm{P} 4$, which was highest among the other treatment groups, starting from the $2^{\text {nd }}$ day until the $10^{\text {th }}$ day post infection. The graph also shows that the infection on the $2^{\text {nd }}$ day in the treatment control group KP (which was infected with P.berghei that had been treated 4 times with artemisinin and were then left untreated) and the treatment group P4 (that was infected with P.berghei and had been treated four times with artemisinin) increased at significantly different rates when compared with the control group K1 (mice that had been infected with P.berghei that had never been treated with artemisinin) and group P1 (infected with P.berghe $i$ and treated once with artemisinin). On the $5^{\text {th }}$ day of infection, group KP showed significantly different increases in neutrophils when compared with the other three groups, namely groups $\mathrm{K} 1, \mathrm{P} 1$, and $\mathrm{P} 4$. On the $8^{\text {th }}$ day of infection, the neutrophil percentage did not show any significant differences between all the groups $(\mathrm{K} 1, \mathrm{KP}, \mathrm{P} 1, \mathrm{P} 4)$. On the $10^{\text {th }}$ day of infection, the neutrophil percentage in group $\mathrm{P} 1$ showed significantly different decreases when compared with the other groups (K1, KP and P4).

Table 1 and Figure 1B show that the highest monocyte percentage was in group P4 when compared with the other treatment groups. The monocytes started to increase on the $2^{\text {nd }}-8^{\text {th }}$ days post infection and then decreased on the $10^{\text {th }}$ day post infection, but the percentage was still higher than in the other treatment groups. These results show that on the $2^{\text {nd }}$ day of infection the KP control group showed significantly different increases when compared with groups K1, P1, and $\mathrm{P} 4$. On the $5^{\text {th }}$ and $8^{\text {th }}$ days of infection the monocytes percentage did not show any significant differences between all groups $(\mathrm{K}, \mathrm{KP}, \mathrm{P} 1, \mathrm{P} 4)$. On the $10^{\text {th }}$ day of infection, group 
Table 1. Distribution of mean leukocyte count by control and treatment groups

\begin{tabular}{|c|c|c|c|c|c|}
\hline \multirow{2}{*}{$\begin{array}{c}\text { Le uko cytes } \\
(\%)\end{array}$} & \multicolumn{4}{|c|}{ Treatment group } & \multirow[b]{2}{*}{$\mathbf{p}$} \\
\hline & Kl (n=5) & KP $(n=5)$ & Pl (n=5) & $\mathrm{P4}(\mathrm{y}=5)$ & \\
\hline \multicolumn{6}{|l|}{ Day 2} \\
\hline Neutrophils & $0.00 \pm 0.00^{2}$ & $20.80 \pm 3.42^{\circ}$ & $6.60 \pm 8.53^{\mathrm{a}}$ & $27.40 \pm 8.76^{\circ}$ & $<0.05$ \\
\hline Monocytes & $0.40 \pm 0.89^{2}$ & $2.00 \pm 1.00^{\mathrm{b}}$ & $0.60 \pm 1.34^{\mathrm{b}}$ & $4.00 \pm 3.16^{\mathrm{c}}$ & $<0.05$ \\
\hline Lymphocytes & $94.00 \pm 6.04^{\mathrm{a}}$ & $75.00 \pm 6.20^{\circ}$ & $90.20 \pm 1169^{\circ}$ & $64.60 \pm 4.87^{\mathrm{b}}$ & $<0.05$ \\
\hline Basophils & $0.00 \pm 0.00^{\mathrm{a}}$ & $1.00 \pm 1.00^{\mathrm{b}}$ & $0.00 \pm 0.00^{\mathrm{a}}$ & $0.40 \pm 0.84 a^{b}$ & $<0.05$ \\
\hline Eosinophils & $5.60 \pm 6.34^{\circ}$ & $1.20 \pm 1.78^{\mathrm{a}}$ & $2.60 \pm 3.71^{b}$ & $3.60 \pm 2.19^{b}$ & $<0.05$ \\
\hline \multicolumn{6}{|l|}{ Day 5} \\
\hline Neutrophils & $12.80 \pm 13.06^{\mathrm{a}}$ & $25.40 \pm 3.71^{\circ}$ & $13.20 \pm 1082^{2}$ & $23.40 \pm 4.87^{2}$ & $<0.05$ \\
\hline Monocytes & $3.40 \pm 1.94^{\mathrm{a}}$ & $1.80 \pm 1.30^{\mathrm{a}}$ & $2.80 \pm 2.77^{\mathrm{a}}$ & $6.20 \pm 5.49^{\mathrm{a}}$ & $>0.05$ \\
\hline Lymphocytes & $78.00 \pm 7.68^{\mathrm{a}}$ & $69.40 \pm 6.65^{2}$ & $82.00 \pm 12.18^{a}$ & $67.60 \pm 7.40^{2}$ & $>0.05$ \\
\hline Basophils & $0.00 \pm 0.00^{\mathrm{a}}$ & $0.20 \pm 0.44^{2}$ & $0.00 \pm 0.00^{2}$ & $2.00 \pm 1.41^{\circ}$ & $<0.05$ \\
\hline Eosinophils & $5.60 \pm 3.91^{a}$ & $3.20 \pm 4.54^{\mathrm{ab}}$ & $2.00 \pm 3.93^{\mathrm{ab}}$ & $0.60 \pm 1.34^{\circ}$ & $<0.05$ \\
\hline \multicolumn{6}{|l|}{ Day 8} \\
\hline Neutrophils & $20.60 \pm 9.71^{\mathrm{a}}$ & $26.40 \pm 3.78^{\mathrm{a}}$ & $25.00 \pm 1469^{\mathrm{a}}$ & $25.00 \pm 8.39^{\mathrm{a}}$ & $>0.05$ \\
\hline Monocytes & $1.20 \pm 1.0^{\circ}$ & $3.60 \pm 2.70^{\mathrm{a}}$ & $9.20 \pm 4.20^{\mathrm{a}}$ & $4.20 \pm 1.48^{\mathrm{a}}$ & $>0.05$ \\
\hline Lymphocytes & $78.20 \pm 9.73^{\mathrm{a}}$ & $69.60 \pm 4.92^{\mathrm{a}}$ & $65.40 \pm 15.12^{a}$ & $69.60 \pm 8.96^{\mathrm{a}}$ & $>0.05$ \\
\hline Basophils & $0.00 \pm 0.00^{\mathrm{a}}$ & $0.20 \pm 0.44^{b}$ & $0.00 \pm 0.00^{\mathrm{a}}$ & $0.60 \pm 0.54^{b}$ & $<0.05$ \\
\hline Eosinophils & $0.00 \pm 0.00^{\mathrm{a}}$ & $0.20 \pm 0.44^{\mathrm{a}}$ & $0.40 \pm 0.89^{2}$ & $0.80 \pm 0.83^{\mathrm{a}}$ & $>0.05$ \\
\hline \multicolumn{6}{|l|}{ Day 10} \\
\hline Neutrophils & $35.00 \pm 8.68^{\mathrm{a}}$ & $28.80 \pm 5.89^{\mathrm{a}}$ & $15.20 \pm 8.75^{\circ}$ & $30.60 \pm 9.83^{2}$ & $<0.05$ \\
\hline Monocytes & $3.00 \pm 2.54^{\mathrm{a}}$ & $1.80 \pm 0.83^{\mathrm{aO}}$ & $7.40 \pm 7.60^{c}$ & $2.80 \pm 1.78^{\mathbf{0}}$ & $<0.05$ \\
\hline Lymphocytes & $60.80 \pm 11.16^{\mathrm{a}}$ & $68.60 \pm 5.54^{\mathrm{a}}$ & $77.40 \pm 5.81^{a}$ & $66.60 \pm 9.53^{2}$ & $>0.05$ \\
\hline Basophils & $0.00 \pm 0.00^{\mathrm{a}}$ & $0.40 \pm 0.54^{2}$ & $0.00 \pm 0.00^{\mathrm{a}}$ & $0.40 \pm 0.89^{\mathrm{a}}$ & $>0.05$ \\
\hline Eosinophils & $1.20 \pm 2.16^{\mathrm{a}}$ & $0.40 \pm 0.54^{\mathrm{a}}$ & $0.00 \pm 0.00^{\mathrm{a}}$ & $0.00 \pm 0.00^{\mathrm{a}}$ & $>0.05$ \\
\hline
\end{tabular}

Values are means \pm SEM. Values for each day along the same rows with different superscript letters are significantly different $(\mathrm{p}<0.05)$; Note: $\mathrm{K} 1=$ control group infected with $P$.berghei and untreated with artemisinin; $\mathrm{KP}=$ treatment controls (infected with P.berghei, treated 4 times with artemisinin and then untreated; P1 $=$ treatment group infected with Plasmodium berghei and treated with a single dose of artemisinin; $\mathrm{P} 4=$ treatment group infected with Plasmodium berghei and treated 4 times with artemisinin

P1 showed significant differences when compared with the other three groups (K1, KP, and $\mathrm{P} 4)$.

Table 1 and Figure 1C show that the highest lymphocyte percentage was in group $\mathrm{P} 4$ when compared with the other groups, starting on the $2^{\text {nd }}$ day until the $10^{\text {th }}$ day post infection. The results show that on the $2^{\text {nd }}$ day of infection groups KP an P4 showed significant differences when compared with groups $\mathrm{K} 1$ and P1. On the $5^{\text {th }}, 8^{\text {th }}$, and $10^{\text {th }}$ days of infection, the lymphocyte percentage did not show any significant differences between all groups (K1, KP, P1, P4) Table 1 and Figure 1D show that the highest basophil percentage was in group $\mathrm{P} 4$ when compared with the other groups, starting on the $2^{\text {nd }}$ day until the $5^{\text {th }}$ day post infection then on the $8^{\text {th }}$ day post infection, the basophil percentage decreased. These results show that on the $2^{\text {nd }}$ day of infection the KP control group showed significantly different increases when compared with groups $\mathrm{K} 1$ and $\mathrm{P} 1$. On the $5^{\text {th }}$ day of infection, group P4 showed significantly different increases in percentages of basophils when compared with the other three groups (K1,KP,P1). On the $8^{\text {th }}$ day of infection, group P4 showed significantly different increases in percentages of basophils when compared with groups $\mathrm{K} 1$ and $\mathrm{P} 1$, but did not show any significant differences with group KP. On the $10^{\text {th }}$ day of infection, the basophil percentage did not show any significant differences between all control and treatment groups (K,KP,P1,P4).

Table 1 and Figure 1E show that the eosinophil percentage in group $\mathrm{P} 4$ was higher the $2^{\text {nd }}$ day post infection. After that, the eosinophil percentage decreased. The image shows that on the $2^{\text {nd }}$ day of infection the KP 


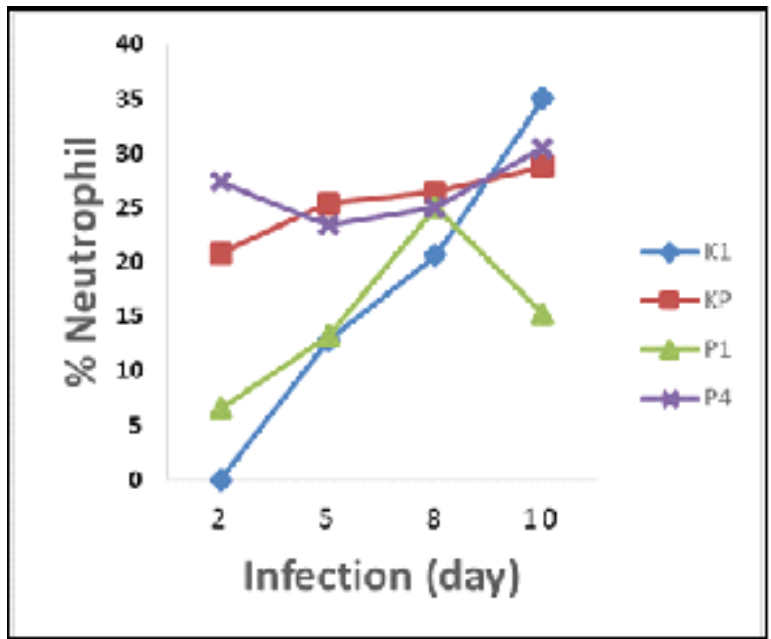

(A)

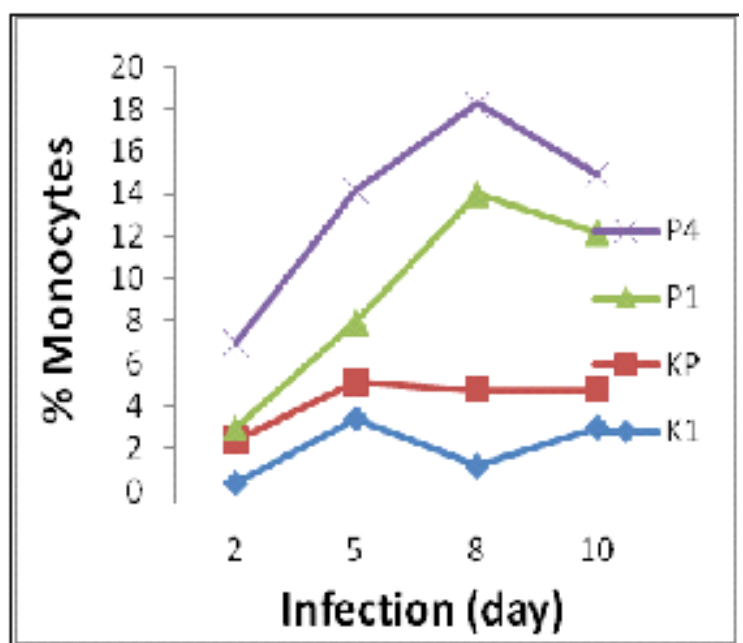

(B)

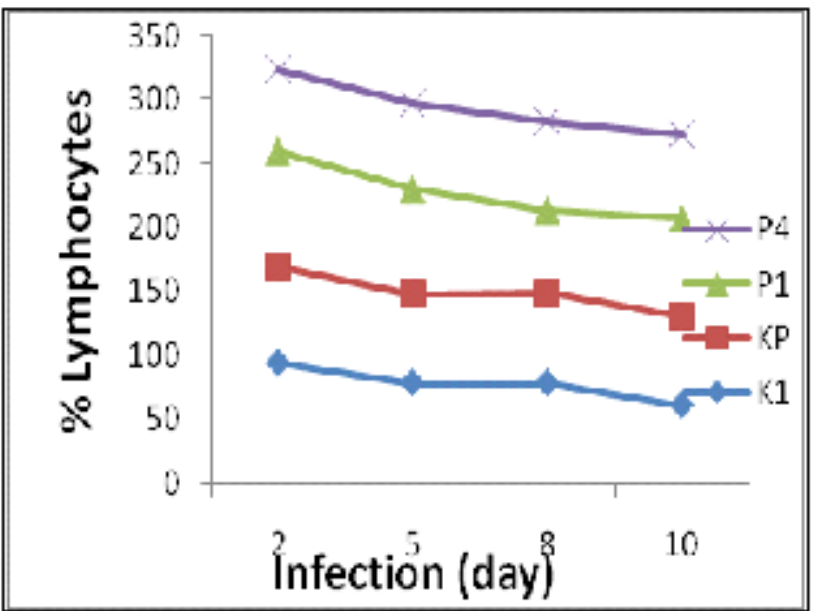

(C)

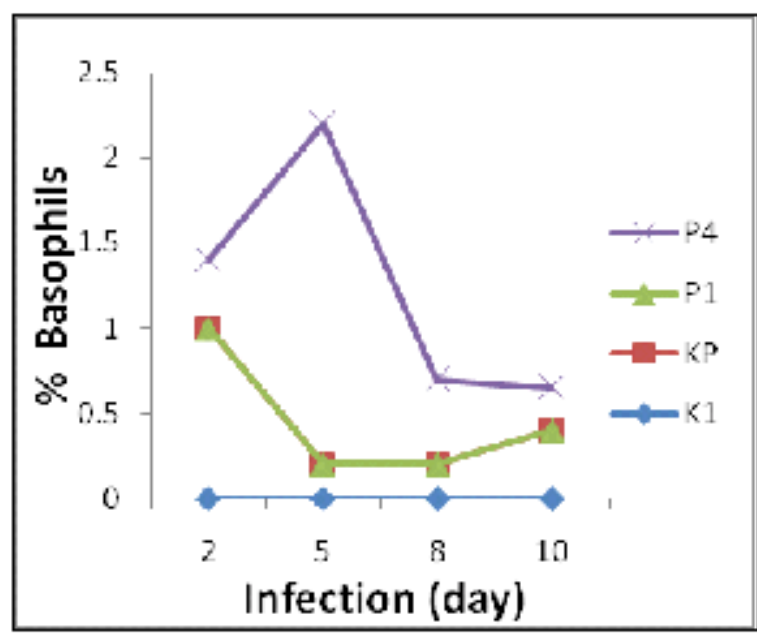

(D)



(E)

Figure 1. Leukocyte type percentage in control and treatment groups repeatedly exposed to artemisinin in mice infected with P.berghei. Note: K1 = control group infected with P.berghei and untreated with artemisinin; $\mathrm{KP}=$ treatment controls (infected with P.berghei, treated 4 times with artemisinin and left untreated); P1 = treatment group infected with Plasmodium berghei and treated with a single dose of artemisinin; P4 = treatment group infected with Plasmodium berghei and treated 4 times with artemisinin 
control group showed significantly different increases when compared with groups $\mathrm{P} 1$ and P4. On the $5^{\text {th }}$ and $8^{\text {th }}$ days of infection, group P4 showed significantly different increases in eosinophil percentages when compared with the K1 control group, but did not show any significant differences with groups KP and P1. On the $10^{\text {th }}$ day of infection, the eosinophil percentage did not show any significant differences between all control and treatment groups $(\mathrm{K}, \mathrm{KP}, \mathrm{P} 1, \mathrm{P} 4)$.

\section{DISCUSSION}

In the present study we showed that neutrophil percentage increased from the $2^{\text {nd }} d a y$ until the $5^{\text {th }}$ day post infection with $P$. berghei. Repeat treatments with artemisinin showed that neutrophils are cells that function as the first line of defense of the body against infection or pathogens entering the body (to eliminate P.berghei). Mice infected with $P$. berghei and treated with a one-time dose of an antimalarial drug yielded the same results as mice treated with a one-time dose of artemisinin (P1), as is shown by the increasing number of neutrophils, monocytes and lymphocytes after more than 5 days of infection. ${ }^{(14)}$ Research with repeated exposure of artemisinin in mice as a model of in vivo in infections in humans has not been done before.

Cytokines and interleukins that are released after lysis of neutrophils will stimulate the bone marrow to release neutrophils so that the production of neutrophils is increased. Malaria infections can induce both humoral and cellular immune responses. In the humoral immune response, antibodies provide protection against malaria infection through a variety of mechanisms. Antibodies can block the invasion of merozoites into erythrocytes and inhibit the growth of parasites in the erythrocytes, while cellular immunity against Plasmodium plays a role in the erythrocytic stage. Cellular immunity is activated by Thelper (Th) lymphocytes, which are a subset of $\mathrm{T}$ cells needed in the induction of immune responses against an invasion of foreign antigens. According to the type of cytokine produced, Th lymphocytes are divided into Th1 cells, which will activate cellular immunity and Th2 cells, which will activate humoral immunity. ${ }^{(15)}$

The increase in neutrophil percentage on the $8^{\text {th }}$ day post infection was not significantly different between groups. On the $10^{\text {th }}$ day post infection, the group of mice infected with P.berghei and treated with a single dose of artemisinin (P1) showed a decrease in neutrophils when compared with groups K1, KP and P4. This shows that neutrophils function as the first line of defense to eliminate P.berghei by phagocytizing parasites and neutrophils on the first days of infection or when the P.berghei attacks. This suggests that infections of longer duration will increase the percentage of parasitemia in the mice so that the high numbers of parasites in their bodies will suppress the immune system (immunosupression), causing the immune system to become inadequate and unable to respond properly. High parasitemia rates will improve the mechanism of parasite invasion and suppress the host immune system. ${ }^{(16)}$

Neutrophils play an important role in the immune response by modulating both cellular and humoral immunity via the synthesis and release of immunoregulatory cytokines. All neutrophil profiles in the groups showed that P.berghei which had been treated with repeated artemisinin showed differences when compared with P.berghei that had never been treated with artemisinin. This shows the infection had become more powerful because of the parasites' ability to develop faster. This is consistent with in vitro studies that were performed by Maslachah (17) who found that Plasmodium which remained viable after repeated artemisinin exposure will increase the parasitemia rate and take a shorter time to become viable again when compared with the parasites in the treatment group which only received a one-time artemisinin exposure.

Monocytes are phagocytic cells that can destroy antigens by ingestion. Moreover, 
monocytes may contribute to delivery of antigens to the lymphocytes (antigen precenting cells, APC). The relatively high increases in the number of monocytes in mice that had been infected with $P$. berghei and exposed repeatedly to artemisinin, resulted in increased phagocytosis of the parasites, this being the body's defense mechanism against P.berghei. Repeat artemisinin therapy in the treatment group causes faster growth of P.berghei that remained viable from medicine exposure, so increasing the parasitemia rate and also the number of cells contributing to the elimination of the parasites, which will affect the monocyte profile.

The treatment control group of mice that were infected P.berghei and had been treated four times with artemisinin and left untreated (KP) showed an increasing average percentage of monocytes that is higher when compared with the control mice that were infected with $P$. berghei and were not exposed to the medicine (K0). This significant difference is visible on the $2^{\text {nd }}$ day post infection. This can be explained from the research results of Maslachah, ${ }^{(17)}$ who found that Plasmodium that have been exposed to artemisinin and are still viable and grow normally, have a faster rate of intra-erythrocytic development, so that the increase in the average percentage of monocytes is a mechanism for defense against $P$.berghei.

The monocyte profile from the $2^{\text {nd }}$ to the $8^{\text {th }}$ day post infection showed an increasing trend in the treated group of mice exposed to artemisinin, but after the $10^{\text {th }}$ day of infection, there was a decrease, whereas in the group of control mice, the trend was decreasing or stable. This shows that after chronic infection, monocyte numbers will be decreased so that the monocytes function maximally in the first week of infection.

The average percentage of lymphocytes in the treated groups of mice showed that had been exposed to artemisinin, seemed to decrease when compared with the control groups. This is because artemisinin treatment for 3 days with a therapeutic dose in mice infected with $P$. berghei caused suppression of Plasmodium growth so that the growth of malaria parasites in all treatment groups was inhibited, as compared with the untreated control group. Research conducted by Teuscher et al. ${ }^{(18)}$ in P. falciparum strains W2 and W2AL80 also showed a decrease in parasitemia rate to $1 \%$ up to 8 days after medicine exposure, when it began to show increases in parasitemia rate, reaching more than $10 \%$ after 12 days.

With regard to the percentage of lymphocytes on the $2^{\text {nd }}$ day of infection, both the treatment control group KP and the treatment group P4 infected with P.berghei that had been repeatedly exposed to artemisinin, showed significant differences when compared with the control group $\mathrm{K} 1$ and the treatment group P1 infected with $P$. berghei and received no treatment and a one-time exposure to artemisinin, respectively This can be explained by the fact that lymphocytes play a role in the body defense mechanism against P.berghei. At the beginning of infection, P.berghei will stimulate the formation of antigen presenting cells (APCs). APCs will stimulate the mice to produce $\mathrm{T}$ lymphocytes that play a role in the immune response to destroy the Plasmodium. However, after the $5^{\text {th }}, 8^{\text {th }}$ and $10^{\text {th }}$ day of infection, the lymphocyte percentage showed no significant differences between all groups of mice. This shows that antigen presenting cells (APC) can affect the response of Tlymphocytes during acute infection in the erythrocytic stage.

In the present study, basophils and eosinophils did not play a major role in infection by the parasite $P$. berghei. Basophils have an important role in the allergic process, while eosinophils play a major role in the process of infection by parasitic worms. ${ }^{(19)}$ The average value of basophils from this study ranged from 0 to $0.4 \%$. These results do not show significantly different increases from the physiological value of basophils of 0 to $0.3 \%$. The percentage of eosinophils was 0 to $5.6 \%$, which did not show a significant increase from the physiological value of eosinophils of $0-4 \%$. On the $2^{\text {nd }}$ day post infection, the basophil and 
eosinophil profiles in the treatment control group KP showed that the groups of mice infected with P. berghei and exposed 4 times to artemisinin had been able to stimulate the production of cells that play a role the immune system (basophils and eosinophils). This suggests that infection with P.berghei that have been exposed repeatedly can stimulate the immune system to work optimally by expressing all types of leukocytes in order to neutralize the infection. Derivatives of artemisisnin (artemether and artesunate) are effective in rescuing mice with late state cerebral malaria and in decreasing leukocyte accumulation in the brain. ${ }^{(11)}$ Many research studies of medicinal plants have shown them to have antimalarial activity by inducing the synthesis of red blood cells, white blood cells and platelets. ${ }^{(20,21)}$

A limitation of this study is that the leukocyte profile data were obtained by using blood smear preparations only, whereas specialized tools are required such as heme analyzers to obtain results with better validity. The clinical implication of this study is that this exposure model of artemisinin with in vivo repeated passages in mice infected with P.berghei can be used as a basis to describe the functioning of the immune system against infections with $P$. berghei parasites which have been exposed to repeated artemisinin. The results of this study can provide a baseline leukocyte profile as one of the immune system's lines of defense against malaria infections caused by $P$. berghei that have repeatedly been exposed to antimalarial drugs, as an in vivo model of malaria in humans.

Further research is needed on the immunologic profile of cytokine-mediated tissue or organ damage. The leukocyte response occurs under normal physiological and pathological conditions. The manifestations of the leukocyte response to malaria infection are in the form of decreases or increases in one or several types of leukocyte, which can provide information and clinical clues that may help in the diagnosis of infections caused by Plasmodium.

\section{CONCLUSION}

Repeated exposure to artemisinin in mice infected with Plamodium berghei will cause changes in leukocyte profile, comprising neutrophils, lymphocytes, monocytes, basophils and eosinophils.

\section{CONFLICT OF INTEREST}

The authors state that there is no conflict of interest with the other authors, publisher or study.

\section{ACKNOWLEDGEMENTS}

We thank the Dean of the Faculty of Veterinary Medicine, Airlangga University, for the provision of funding from the Annual Workplan and Budget (Rencana Kerja dan Anggaran Tahunan, RKAT) for this research.

\section{CONTRIBUTION}

LM contributed to drafting the manuscript and the design of the study. LM and RS contributes to data collection, analysis and interpretation. LM contributed revising manuscript for critically important content. All authors read and approved the final manuscript.

\section{REFERENCES}

1. World Health Organization. WHO global malaria programme: world malaria report 2015. Geneva: World Health Organization;2015.

2. Afonso A, Hunt P, Cheesman S, et al. Malaria parasites can develop stable resistance to artemisinin but lack mutations in candidate genes atp6 (encoding the sarcoplasmic and endoplasmic reticulum Ca2+ ATPase) tctp, mdr1 and cg10. Antimicrob Agents Chemother 2006; 50:480-9.

3. Noedl H. Evidence of artemisinin resisntant malaria in Western Cambodia. N Engl J Med 2008;359:2619-620.

4. Wongsrichanalai C, Meshnick SR. Declining artesunate-mefloquine efficacy against 
falciparum malaria on the Cambodia-Thailand border. Emerg Infect Dis 2008;4:716-8.

5. Maslachah L, Dachlan YP, Nidom CA, et al. Profil fenotipik Plasmodium falciparum galur Papua 2300 akibat paparan antimalaria artemisinin in vitro. MKB 2015;47:1-9.

6. Paloque L, Ramadani AP, Mercereau-Puijalon O, et al. Plasmodium falciparum: multi faceted resistance to artemisinins. Malar J 2016;15:149. DOI: 10.1186/s12936-016-1206-9.

7. Njokah MJ, Kang JN, Kinyua J, et al. In vitro selection of Plasmodium falciparum Pfcrt and Pfmdrl variants by artemisinin. Malar $\mathrm{J}$ 2016;15:381. doi: 10.1186/s12936-016-1443-y.

8. Craig AG, Grau GE, Janse C, et al. The role of animal models for research on severe malaria. PLoS Pathogens 2012;8:2 e1002401.

9. Darlina, Raharjo T, Nurhayati S. Changes of leukocytes type in mice immunized with irradiated Plasmodium berghei. National Seminar, 16 November,Yogyakarta;2011.

10. Darlina, Krisnanto T, Fauzan A. Haematopoietic response of mice infected with erythrocytic stadium of gamma irradiated Plasmodium berghei. Indonesian J Nuclear Sci Technol 2012; 13:85-94.

11. Clemmer L, Martin YC, Zanini GM, et al. Artemether and artesunate show the highest efficacies in rescuing mice with late stage cerebral malaria and rapidly decrease leukocyte accumulation in brain. Antimicrob Agents Chemother 2011;55:1383-90.

12. Kiboi DM, Irungu BN, Langat B, et al. Plasmodium berghei ANKA: selection of resistance to piperaquine and lumefantrine in a mouse model. Exp Parasitol 2009;122:196-202.

13. Henriques G, Martinelli A, Rodrigues L, et al. Artemisinin resistance in rodent malariamutation in the AP2 adaptor $\mu$-chain suggest involvement of endocytosis and membrane protein trafficking. Mal J 2013;12:118.
14. Odeghe OB, Uwakwe AA, Monago CC. Some biochemical and haematological studies on the methanolic extract of Anthocleista grandiflora stem bark. Int J Appl Sci Technol 2012;2:58-65.

15. Baratawidjaja KG, Rengganis I, editors. Imunologi dasar. Edisi ke 9. Jakarta: Balai Penerbit Fakultas Kedokteran Universitas Indonesia;2010.

16. Onwuamah CK, Phillip UA, Odeigah PG. Mouse mortality from a high plasmodium berghei inoculum density may be due to immune suppression in the host. Int J Med Med Sci 2010; 2:162-6.

17. Maslachah L. Efek paparan artemisinin berulang terhadap perkembangan Plasmodium falciparum resisten in vitro [Disertasi]. Surabaya; Universitas Airlangga;2013.

18. Teuscher F, Chen N, Kyle DE, et al. Phenotypic changes in artemisinin resistant Plasmodium falciparum line in vitro: Evidence for decreased sensitivity to dormancy and growth inhibition. Antimicrob Agent Chemother 2012;56:428-31.

19. Fabre V, Beiting DP, Bliss SK, et al. Eosinophil deficiency compromises parasite survival in chronic nematode infection. J Immunol 2009; 182:1577-83.

20. Balogun EA, Adebayo JO, Zailani AH, et al. Activity of ethanolic extract of Clerodendrum violaceum leaves against Plasmodium berghei in mice. Agric Biol J N Am 2009;1:307-12.

21. Anggraini R, Widodo GP, Ningsih D. Antiplasmodium effect of Mundu (Garcinia dulcis Kurz) cortex $\mathrm{N}$ hexane extract with leukocyte and hemoglobin amount parameter on Swiss Webster mouse infected with Plasmodium berghei. Indonesian Pharmacy J 2011;8:45-52. 